\section{EMBRYRIDDLE}

Aeronautical University

SCHOLARLY COMMONS
Journal of Aviation/Aerospace Education \& Research

Volume 23

Number 1 JAAER Fall 2013

Article 8

Fall 2013

\title{
The Wright Lawsuit
}

David Freiwald

dfreiwald@gmail.com

Follow this and additional works at: https://commons.erau.edu/jaaer

\section{Scholarly Commons Citation}

Freiwald, D. (2013). The Wright Lawsuit. Journal of Aviation/Aerospace Education \& Research, 23(1). https://doi.org/10.15394/jaaer.2013.1604

This Article is brought to you for free and open access by the Journals at Scholarly Commons. It has been accepted for inclusion in Journal of Aviation/Aerospace Education \& Research by an authorized administrator of Scholarly Commons. For more information, please contact commons@erau.edu. 


\title{
THE WRIGHT LAWSUIT David Frelwald
}

\begin{abstract}
While the flights of the Wright brothers over a century ago have enshrined their names in aeronautical history, only slightly less important are the lawsuits brought forth by the brothers in defense of their invention. From 1906 to 1917 the Wright brothers maintained a successful stranglehold on the development and production of the airplane in the United States. This paper examınes that history, the ensuing litigation, and the impact that the Wright brothers actions had upon the readiness of the U.S. in World War I.
\end{abstract}

\section{The Wright Lawsuit}

The Wright brothers were granted a patent by the U.S. Patent Office in 1906 for a flyıng machıne (U.S. Patent No. 821,393, 1906). This patent was based on the application they had submitted in 1903 that had included a detailed description and drawings of their control system as applied to a glider (Crouch, 1981). Their application described wing warping, as well as the entire system that allowed the arcraft to be controlled in forward flight (Wright \& Wright, 2011). The Wrights had also stated in their application that a feature like ailerons could provide lateral control (U.S. Centennial of Flight Commission, 2005). Obtaining a patent meant that no one could copy the Wrights' design without their permission and without paying them a royalty. However, the success of the Wrights' design, bolstered by Chanute's subsequent publication of their achievements, proved impossible for other arrcraft designers to ignore. Furthermore, the concept of lateral control was so basic to any aircraft design that, without it, no aircraft could have flown successfully (Heppenheimer, 2003).

\section{Wright and Wright v. the World: A Primer}

After the success of the June Bug, the members of Alexander Graham Bell's Aerial Experiment Association designed and built its final arrplane, the Silver Dart. It was the first American arrcraft built by a team other than the Wright brothers that performed well enough to be considered a practical aurcraft (Goddard, 2003). Bell told the members that they had not trespassed on the Wright patent.
In the midst of these discussions, Curtiss received a telegram from Augustus Herring suggesting that the two form a partnership to build airplanes (Shulman, 2002).

Curtiss unveiled the Aeronautical Society machıne, which he called the Golden Flyer, on June 16, 1909 flyıng it from Morris Park in the Bronx. To further differentiate his aurplane designs and the Wrights', he mounted ailerons between the wings of the biplane. On July 17, he flew the Golden Flyer for 25 miles and captured the Scientific American Trophy for the second year in a row (Shulman, 2002). This exceeded the Wright's patience and Wilbur filed a patent-infrngement suit against Curtiss on August 16 and another on August 19 seekıng to prevent the Aeronautical Society from flying the Golden Flyer (Banner, 2008). Curtiss' subsequent success at Rhelms did little to assuage Wilbur's anger (Brady, 2000).

\section{The Wrights' Position: A Propositional Fallacy}

Because of the experiences and values gained from their clergyman father, the brothers could be best described as hyper-vigilant towards those whom they perceived as less ethically bound and therefore likely to steal their invention (Howard, 1988). This mindset led to the selection of the 1solation of Kitty Hawk, the silver paint of the aircraft, and the retreat to Dayton - all founded in a belief that the press and public scrutiny would result in a loss of control of their design (Brady, 2000). Orville warned Curtiss on July 20, 1908, "We do not intend to give permission to use the patented features of our machınes for exhibitions or in a commercial way. [...] If it is your desire to enter the 
exhibition business, we would be glad to take up the matter of a license to operate under our patents for that purpose" (Wright \& Wright, 2011, p. 907). Clearly, the Wrights saw their patent applying to all airplane flight as a consequence of their successful desıgn (Banner, 2008). This belief was so broadly applied that it led to an unnamed Curtiss employee to remark, "If you jump in the air and flap your hands, the Wright Brothers will sue!" (White, 2011, para. 1)

As Bradshaw (1992) notes, it is known from the literature that the Wright's progress was wholly iterative: they did not use the traditional desıgn-build-test feedback loop of a sole-source inventor, they focused on the refinement of components using knowledge obtained from Chanute and others. No invention, no scientific discovery, no work of art, no human endeavor happens in an historical vacuum. There are always other factors - cultural, political, and personal - that influence the outcome of a single event. So it was with the invention of the arrplane. A translation of Lilienthal's Birdflight as the Basis of Aviation (1911) was discovered in the Special Collections area of the EmbryRiddle library with evidentiary markıngs from the U.S. Court of Claims indicating that the book belonged to the Wrights at the time of its seizure in 1929, prima facle evidence that the knowledge that made their first powered flight possible was not entirely self-synthesized. Though the printing of the text postdates their first flight the content within precedes it by a decade and a half.

Unfortunately for Curtiss, when the final verdict came in 1913 Orville Wright, now without Wilbur, was the unmistakable winner. With all delays and appeals exhausted, the Federal Circuit Court of Appeals ordered Curtiss to cease makıng airplanes with two ailerons that operated simultaneously in opposite directions (Freudenthal, 1949). After consulting with Henry Ford, their mutual lawyer encouraged Curtiss to bait Orville to reopen the litigation by devising a new configuration for lateral control using the Langley aerodrome that hung in the Smithsonian (Kelly, 1989). The idea was to persuade the court that Curtiss' plane was based on Langley's design, not on the Wrights', an attempt that was unsuccessful, but ensured that the case dragged on. Ford's lawyer was able to persuade the court to temporarily stay the old verdict, and the legal challenges began again (Shulman, 2002).

The suit finally ended with the start of World War I when the aircraft manufacturers established the Manufacturers' Aurcraft Association to coordinate wartime aurcraft manufacturing in the United States and formed a patent pool with the approval of the U.S. government Kane, 2003). All patent litigation ceased automatically and royalties were reduced to one percent and the free exchange of inventions and ideas took place among all the airframe builders. While this arrangement was to have lasted only for the duration of the war, the litigation was never renewed at the end of the war in 1918. By this time, Orville had sold his interest in the Wright Company to a group of New York financiers and had retired from the business (Kelly, 1989). For the war effort, however, the damage had already been done.

The Effect of the Lawsuit upon the Development of Aviation in the United States

The aeronautical world in 1918 would be unrecognizable to Wilbur Wright who had left it only six years earlier. As late as 1914, the worldwide arrcraft industry employed only a few hundred workers. By 1918 , over 350,000 people were dependent upon the new industry that had manufactured over 50,000 aurcraft as a consequence of World War I (Goddard, 2003).

By the time the United States had entered World War I, other countries had pulled far ahead in production. As early as 1913, a year before hostilities commenced on the continent, France appropriated $\$ 74$ million for aviation. By contrast, Amenca's spending of $\$ 125,000$ approximated that of Bulgaria (Goddard, 2003). When the assassination for the Archduke catapulted the continent into war there were already several hundred serviceable aircraft available - even if their mission had yet to be well defined.

The United States did not produce any arrcraft of its own design for use at the front during World War I; nevertheless, the war served as an impetus for the infant industry and gave several arrcraft companies their start. Most wartime production revolved around the manufacture of training aurcraft, of the British De Havilland DH-4 bombers and reconnaissance aircraft, and of aircraft engines, where the automobile companies dominated (Brady, 2000). Federal policy during the war dictated that the government should not rely exclusively on private industry for all its aircraft needs as a direct result of the past decade of patent squabbles. Consequently, the U.S. government established the Naval Aurcraft Factory (NAF) at the Philadelphia Shipyards to design and produce wartime aircraft as well as serve as a check on industry costs and profits. Although industry resisted its establishment and its intrusion into the private sector, the NAF succeeded in designing and producing a number of naval arrplanes. Its production included 50 Curtiss $\mathrm{H}-16 \mathrm{~s}$, and a total wartime production of 183 flying boats plus spare parts for the craft (U.S. Centennial of Flight Commission, 2005). 


\section{Conclusion}

History is not especially kind to the Wright brothers where the arrplane business is concerned. Their aircraft company did not prosper; it struggled along for six years until it was finally sold (Kelly, 1989). Durng that time, the firm lost its technological lead and Wright arrplanes became hopelessly obsolete. The brothers alienated much of the aviation community with therr patent lawsuits and then, when they won those suits Orville alienated the investors in the Wright Company by refusing to take full advantage of their legal position. Consequently, many histonans judge Wilbur and Orville Wright to be as inept in business as they were brilliant in engineering. Sadly, their obstinacy led to a strategic disadvantage for the United States in World War I. If the promise to "darken the skies over Germany" with the "greatest aenal armada ever seen" (Hughes, 1919, p. 897) had been able to be fulfilled one must wonder how many men on both sides of the conflict might have been spared the prolonged misery of the trenches. In this we can see that the real losers of the Wright lawsuits were not the aviation pioneers but those who would come to depend upon the arrplane as a valued tool in the swift prosecution of warfare.t

David Freıwald is an assıstant professor of aerospace and occupational safety at Embry-Rıddle Aeronautical Unıversity Daytona Beach, Flonda. 


\section{Refereneces}

Banner, S. (2008). Who owns the sky? The struggle to control airspace from the Wright brothers on. Cambridge: University Press.

Bradshaw, G.L. (1992). The arrplane and the logic of invention. In R.N. Giere (Ed.), Cognitive Models of Science. Minneapolis, MN: The Unıversity of Minnesota Press.

Brady, T. (Ed.). (2000). The American aviation experience: A history. Carbondale, IL. Southern Illinois University Press.

Crouch, T. (1981). Dream of wings: Americans and the Airplane, 1875-1905. New York: W W Norton.

Freudenthal, E. (1949). Flight into history: The Wright brothers and the air age. Norman, OK. University of Oklahoma Press.

Goddard, S. (2003). Race to the sky: The Wright brothers versus the United States. Jefferson, NC: McFarland \& Company.

Heppenheimer, T. (2003). First flight: The Wright brothers and the invention of the airplane. Hoboken, NJ: John Wiley \& Sons.

Howard, F (1988). Wilbur and Orville: A biography of the Wright brothers. Mineola, NY Dover.

Hughes, C. (1919, January 3). Report on aircraft production inquiry. Cong. Rec. 57, 3, p. 897

Kane, R. (2003). Air transportation. 14th ed. Dubuque: Kendall/Hunt.

Kelly, F (1989). The Wright brothers: A biography. Mineola, NY Dover.

Lilienthal, O. (1911). Birdflight as the basis of aviation, a contribution towards a system of aviation, compiled from the results of numerous experiments made by $O$. and $G$. New York: Longmens Green.

Shulman, S. (2002). Unlocking the sky: Glenn Hammond Curtiss and the race to invent the aurplane. (1st ed.). New York: Harper Perennial.

U.S. Centennial of Flight Commission. (2005). Wright brothers history Retrieved from http://www.centennialofflight.gov/wbh/index.html

White, J. (2011, July 21). The airplane patent wars. Retrieved from http://all-thıngs-aviation.com/aviation/the-aurplane-patentwars/

Wright, W., \& Wright, O. (1906). U.S. Patent No. 821,393. Washıngton, DC: U.S. Patent and Trademark Office

Wright, W., \& Wright, O. (2011). The papers of Wilbur and Orville Wright, 1899-1905: Including the Chanute-Wright letters and Other Papers of Octave Chanute. (Vol. 1). Whitefish, MT Literary Licensing. 